\title{
Quantifiable urine glyphosate levels detected in $99 \%$ of the French population, with higher values in men, in younger people, and in farmers
}

\author{
Daniel Grau ${ }^{1} \cdot$ Nicole Grau ${ }^{1} \cdot$ Quentin Gascuel ${ }^{1}$. Christian Paroissin ${ }^{2} \cdot$ Cécile Stratonovitch $^{3} \cdot$ Denis Lairon ${ }^{4}$. \\ Damien A. Devault ${ }^{5}$. Julie Di Cristofaro ${ }^{6}$
}

Received: 23 July 2021 / Accepted: 10 December 2021 / Published online: 12 January 2022

(c) The Author(s) 2021

\begin{abstract}
France is the first pesticide-consuming country in Europe. Glyphosate is the most used pesticide worldwide and glyphosate is detected in the general population of industrialized countries, with higher levels found in farmers and children. Little data was available concerning exposure in France. Our objective was to determine glyphosate levels in the French general population and to search for an association with seasons, biological features, lifestyle status, dietary habits, and occupational exposure. This study includes 6848 participants recruited between 2018 and 2020. Associated data include age, gender, location, employment status, and dietary information. Glyphosate was quantified by a single laboratory in first-void urine samples using ELISA. Our results support a general contamination of the French population, with glyphosate quantifiable in $99.8 \%$ of urine samples with a mean of $1.19 \mathrm{ng} / \mathrm{ml}+/-0.84$ after adjustment to body mass index (BMI). We confirm higher glyphosate levels in men and children. Our results support glyphosate contamination through food and water intake, as lower glyphosate levels are associated with dominant organic food intake and filtered water. Higher occupational exposure is confirmed in farmers and farmers working in wine-growing environment. Thus, our present results show a general contamination of the French population with glyphosate, and further contribute to the description of a widespread contamination in industrialized countries.
\end{abstract}

Keywords Glyphosate · France · General population · Dietary habits · Occupational exposure

Responsible Editor: Philippe Garrigues

Julie Di Cristofaro

julie.dicristofaro@efs.sante.fr

Association Campagne Glyphosate, Foix, France

2 Université de Pau Et Des Pays de L'Adour, CNRS, LMAP, E2S UPPA Pau, France

3 ARSEAA, Pôle Guidance Infantile, Psychiatrie Infanto-juvénile Secteur III, Labège, France

4 Faculté de Médecine de La Timone, Aix Marseille Université, INSERM, INRA, C2VN Marseille, France

5 Centre Universitaire de Formation Et de Recherche de Mayotte, Dembeni, Mayotte, France

6 ADES, Aix Marseille University, CNRS, EFS, Marseille, France

\section{Introduction}

Following World War II, the French agricultural model evolved through mechanization, crop improvement, and increased use of chemicals (plant protection products and fertilizers). Agriculture became more professional and specialized. In the last 40 years, the number of French farmers decreased from 1.61 million in 1982 to 0.4 million in 2019 . Accordingly, 1.1 million farms were recorded in 1988 vs. 0.45 million in 2013. Nowadays, 29 million hectares (ha) are dedicated to agriculture (54\% of the French surface area), with an average of 61 ha per farm. Farm sizes vary greatly according to crop production: 87 ha per farm for cereal production down to 10 ha for horticulture or market gardening (Agreste 2020b, d, e, INSEE 2020).

The use of pesticides resulted in the discharge of residues into the environment, ecosystem, and food chain (Hussain et al. 2015, Schulz et al. 2021). Despite the recent marked progression of organic production (Agreste 2020c), 
the purchase and use of pesticides in French agriculture increased by 25\% during the last decade (Mandard 2020). France is among the world's top ten pesticide-using countries (WorldAtlas 2021). In 2017, chemical weed control increased in almost all large-scale crops areas; data from the French Ministry of Agriculture indicate that the number of chemical sprays (herbicides, fungicides, pesticides) per crop range between 33 and 2.7, in decreasing order for fruit, wine, vegetable, and cereal farming (Agreste 2020a, e).

Glyphosate, put on the market in 1974 under the trade name "Roundup," is the world's most widely used broadspectrum herbicide and crop desiccant, usually sprayed on weeds or some crops before harvest (Woodburn 2000). Glyphosate, or $N$-(phosphonomethyl) glycine, an organophosporus compound (phosphonate) (Franz 1974), blocks a metabolic pathway essential for the plant's growth (Steinrucken and Amrhein 1980).

The glyphosate Maximum Residue Limit (MRL) in France for drinking water is $0.1 \mathrm{ng} / \mathrm{ml}$. In solid food, MRL is higher and reaches $20 \mathrm{mg} / \mathrm{Kg}$ for cereals, like oats $(20 \mathrm{mg} /$ $\mathrm{Kg})$, barley $(20 \mathrm{mg} / \mathrm{Kg})$, wheat $(10 \mathrm{mg} / \mathrm{Kg})$ or lentils $(10 \mathrm{mg} /$ $\mathrm{Kg}$ ), beans $(2 \mathrm{mg} / \mathrm{Kg})$, peas $(10 \mathrm{mg} / \mathrm{Kg})$, and canola seeds $(10 \mathrm{mg} / \mathrm{Kg}$ ) (ANSES 2016, 2019). In France, glyphosate was found in $53 \%$ of food samples, including $87.5 \%$ of breakfast cereals; concentrations ranged from $40 \mu \mathrm{g} / \mathrm{Kg}$ for a breakfast cereal to $2100 \mu \mathrm{g} / \mathrm{Kg}$ for a sample of dry lentils (GénérationsFutures 2017). Another study conducted in France showed that glyphosate was found in $100 \%$ of infant cereal samples (ANSES 2016). In 2007, 9.5\% of cereal samples tested in Europe by the European Food Safety Authority (EFSA) contained glyphosate. A study carried out in Switzerland on foods purchased in supermarkets found the highest levels of glyphosate in cereals and in pasta (Zoller et al. 2018). Glyphosate was also detected in beverages; in Germany, 6 out of 14 beers tested positive for glyphosate. All wines and fruit juices tested in Switzerland contained glyphosate (Zoller et al. 2018).

Human exposure to glyphosate, either by food and water intake or via external exposure, has been extensively studied. However, because of differences in methodology between studies, direct data comparison is difficult (Connolly et al. 2020a).

In the general population, the main route of exposure appears to be food, with higher levels of exposure in developing countries (Acquavella et al. 2004). Glyphosate was found in urine in the majority of studies (Gillezeau et al. 2019; Connolly et al. 2020a). Glyphosate was found in the urine of nearly half of the non-user volunteers from 18 European countries (IARC 2015). A literature review (Connolly et al. 2020a) reported that around $70 \%$ of urine samples were positive for glyphosate in the general population, with arithmetic mean concentrations varying between $0.28 \mathrm{ng} / \mathrm{ml}$ (McGuire et al. 2016) and $7.6 \mathrm{ng} / \mathrm{ml}$ (Varona et al. 2009).
In Europe, a retrospective analysis of urine samples from Germany collected between 2001 and 2015 analyzed by GC-MS/MS (Gas Chromatography-Mass Spectrometry) reported glyphosate concentrations at or above the limit of quantification of $0.1 \mathrm{ng} / \mathrm{ml}$ in $31.8 \%$ samples, with a peak in $2012(57.5 \%)$ and 2013 (56.4\%) with median concentration slightly above the limit of quantification (LOQ) (Conrad et al. 2017). Connolly et al., validating a GC-MS protocol with a LOQ of $0.05 \mathrm{ng} / \mathrm{ml}$, detected glyphosate in $66 \%$ of German urine samples (Connolly et al. 2020b). In a recent study conducted on Portuguese adults who mainly ate organic food, glyphosate measured in urine by GC-MS/MS was detected in $28 \%$ of samples (median value of $0.25 \mathrm{ng}$ / $\mathrm{ml}$ ) collected in July and detected in $73 \%$ of samples collected in October and analyzed by HPLC-MS/MS (highperformance liquid chromatography-mass spectrometry) (median value of $0.13 \mathrm{ng} / \mathrm{ml}$ ) (Nova et al. 2020).

Men tend to have a higher mean urine concentration of glyphosate than women, and children a higher mean concentration than adults (Curwin et al. 2007; Conrad et al. 2017).

Recent European studies analyzed glyphosate levels in children; a study from Denmark showed that children presented higher glyphosate levels than their mother (Knudsen et al. 2017). This was confirmed by a German study reviewed in (Gillezeau et al. 2019); Lemke et al. (Lemke et al. 2021) showed that $52 \%$ of 2,144 first-void urine samples from German children and adolescents aged 3-17 years old had glyphosate level above the LOQ $(0.1 \mathrm{ng} / \mathrm{ml})$ with a geometric mean concentration of $0.107 \mathrm{ng} / \mathrm{ml}$. Ferreira et al. (Ferreira et al. 2021) also detected glyphosate in $95.1 \%$ of 41 urine samples from Portuguese children (2-13 years old), with an arithmetic mean of $1.77 \mathrm{ng} / \mathrm{ml}$ and reaching a maximum value of $4.35 \mathrm{ng} / \mathrm{ml}$. These authors reported values from previous studies conducted in children, with detection rates ranging from 11.1 to $100 \%$, arithmetic mean values from 0.1 to $2.7 \mathrm{ng} / \mathrm{ml}$, and maximum values from $<0.1$ to $18 \mathrm{ng} / \mathrm{ml}$ (reviewed in (Ferreira et al. 2021)).

Pregnant women are also exposed to glyphosate (Parvez et al. 2018). In France, $43 \%$ of pregnant women had glyphosate in their urine (average $0.2 \mathrm{ng} / \mathrm{ml}$ and maximum $0.76 \mathrm{ng} /$ ml) (Chevrier et al. 2009). An American multicenter survey observed glyphosate in 95\% (LOD $0.014 \mathrm{ng} / \mathrm{ml}$ ) of 2nd trimester maternal urine samples by UPLC-MS/MS (Ultra Performance Liquid Chromatography) with a median of $0.22 \mathrm{ng} / \mathrm{ml}$ (0.01 to $1.9 \mathrm{ng} / \mathrm{ml}$ ) (Lesseur et al. 2021). In addition, Ruiz et al. (Ruiz et al. 2021) detected glyphosate in urine from $54 \%$ of Spanish breastfeeding mothers $(n=97)$ with a geometric mean of $0.12 \mathrm{ng} / \mathrm{ml}$.

Occupational exposure occurs via the skin and via respiratory and digestive tracts, and is also valid for people living near agricultural holdings. Farmers and their families presented higher glyphosate levels than the general population; with glyphosate arithmetic mean levels reported in urine after 
work between $1.35 \mathrm{ng} / \mathrm{ml}$ in Europe (Connolly et al. 2017) and $292 \mathrm{ng} / \mathrm{ml}$ in China (Zhang et al. 2020). Glyphosate levels are also reported to be higher in farmers' children (Jauhiainen et al. 1991; Curwin et al. 2007).

Important human health concerns have been raised regarding glyphosate exposure. The International Agency for Research on Cancer (IARC), a specialized agency of the World Health Organization (WHO), linked non-Hodgkin lymphoma (NHL) to glyphosate exposure and classified glyphosate as a "probable carcinogenic (Group 2 A)" (IARC 2015); this association has been further confirmed (Leon et al. 2019; Zhang et al. 2019; Inserm 2021), whereas the evaluation conducted by the European Food Safety Authority (EFSA) concluded that glyphosate is "unlikely to pose a carcinogenic hazard to humans and the evidence does not support classification with regard to its carcinogenic potential" (EFSA 2015). Evaluation by the EFSA mostly relied on studies conducted by agrochemical industries (Portier et al. 2016; Benbrook 2019; Foucart 2021a, b).

Some studies associated glyphosate herbicides to neurotoxic effects and impaired neurodevelopment (Nevison 2014; de Araujo et al. 2016; von Ehrenstein et al. 2019; Ongono et al. 2020); nephrotoxic mechanisms (Jayasumana et al. 2014; Gunarathna et al. 2018; Gunatilake et al. 2019); and endocrine disrupting effects, especially concerning sexual hormones (Savitz et al. 1997; Garry et al. 2002; Dallegrave et al. 2007; Alarcon et al. 2019; Manservisi et al. 2019; Ingaramo et al. 2020; Jarrell et al. 2020).

Due to the use of glyphosate in French agriculture, with available data indicating that glyphosate is frequently present in the food supply, we hypothesized that a large percentage of the French population would be contaminated by glyphosate.

Our aim in the present study was to evaluate the frequency and levels of glyphosate contamination in the French population, nationwide. We also aimed to determine a potential association of urine glyphosate levels with the seasons, subject characteristics, lifestyle status, dietary habits, or occupational exposure.

Based on the observation that measuring the concentration of glyphosate on a single urinary spot after an overnight fast is a reliable estimate of maximum glyphosate excretion in humans (Faniband et al. 2021), glyphosate was quantified in first-void urine samples from 6848 volunteer participants recruited throughout metropolitan France and in La Reunion Island (Indian Ocean).

\section{Material and methods}

\section{Participants, sample, and data collection}

The study was designed by the Campagne Glyphosate France Association (Foix, France). Participant recruitment was organized and conducted by French local committees between June 2018 and January 2020. One hundred and seventy-five sessions were organized in 63 French districts.

All subjects gave written informed consent to participate in the study prior to sample collection. No exclusion criteria were used to exclude potential participants.

A total of 6848 participants were recruited. Participants were asked not to urinate, drink, eat, or smoke at least $6 \mathrm{~h}$ before urine collection.

Prior to urine collection, a written questionnaire was filled in by each participant providing self-reported socio-demographic and lifestyle information. Collected data included age, gender, height and weight, employment status, place of residence, smoking status, physical activity practice, general dietary information (organic food consumption; beer and fruit juice consumption; tap, bottled, spring (well or natural source) or filtered water consumption). The questionnaire also included whether the participant had complied with the protocol before urine collection.

All samples were processed according a unique standardized protocol: anonymized first-void urine samples were collected in polypropylene centrifuge tubes (Nerbe Plus, Germany; \#02-502-3001), incubated $10 \mathrm{~min}$ at $70{ }^{\circ} \mathrm{C}$ for stabilization and shipped at room temperature (RT) to Biocheck GmbH (Germany) for further analysis.

\section{Urine glyphosate quantification}

Urine samples were analyzed for glyphosate residue levels using the glyphosate Enzyme-linked immunosorbent assays (ELISA) kit (Abraxis, Inc., USA; \#500,086). The glyphosate ELISA kit quantification range in water on a direct sample is $0.075-4 \mathrm{ng} / \mathrm{ml}$. Quantitative analytical method validation for water samples, performed by the Ontario Ministry of the Environment, showed that the correlation coefficient between LC-MS and ELISA was 0.804 (Abraxis Eurofin (Parmar)) and 0.88 according to another validation study (Byer et al. 2008). Quantification of glyphosate by ELISA in water samples evaluated according to HPLC showed a correlation of 0.99 (Clegg et al. 1999); similar performance of both methods were further confirmed (Rubio et al. 2003).

Urine samples were analyzed according to the manufacturer's protocol, as validated by Krüger et al. (Krüger et al. 2014) based on ELISA and GC-MS assay data comparison on human urine samples.

All assays were performed by a single laboratory Biocheck GmbH. ELISA was performed according to the manufacturer's protocol intended for human urine samples. Briefly, $500 \mu \mathrm{l}$ of urine sample were filtered with a $3 \mathrm{~K} \mathrm{VWR}$ Centrifugal filter at $3000 \times g$ for $10 \mathrm{~min}$ and the upper layer was transferred to a new tube and analyzed according to the Glyphosate Plate ELISA Kit user's guide. Samples with glyphosate concentrations higher than $4 \mathrm{ng} / \mathrm{ml}$ were diluted 
at a 1:5 ratio with the Glyphosate Sample Diluent provided in the kit and reanalyzed. Measurements were performed on a Sunrise Microplate Reader automate (Tecan, Switzerland). Standard deviation measured by intra-day and inter-day samples reported by Biocheck $\mathrm{GmbH}$ is $0.13 \mathrm{ng} / \mathrm{ml}$.

\section{Statistical analyses and data interpretation}

The participant data used in this study have been anonymized in the database. Glyphosate measurements and self-reported participant data on socio-demographic and lifestyle characteristics are reported as numbers, percentages or mean with range or standard deviation (SD). Geographical data are plotted on a map.

Glyphosate measurements were adjusted according body mass index (BMI, calculated as weight/height ${ }^{2}$ ) as proposed in (Boeniger et al. 1993). Differences in glyphosate concentrations according to each variable (age, gender, employment status, place of residence, smoking status, physical activity, dietary information) were assessed using ANOVA or Kruskal-Wallis tests.

All analyses were performed using R Environment for statistical computing (RCoreTeam 2020). The statistical significance level was set to $\alpha=0.05$.

\section{Results}

\section{Population characteristics}

Among the 6848 urine samples collected, 53 (0.8\%) could not be used and were excluded from further analysis; the cohort therefore included 6795 urine samples. Date and location of collection were available for all samples. Geographical location of participants' place of residence is mapped in Fig. 1.

Five thousand eight hundred (5800) questionnaires filled in by these participants providing self-reported information were analyzed and further included in association analyses.

Participant characteristics are given in Table 1; 82\% of participants self-reported compliance to the protocol, the median age was 53 years [0.5-94], and $M / F$ sex ratio was 0.85. BMI, calculated according to height and weight, is presented in Table 1 according the WHO classification. Concerning lifestyle status, $11.0 \%$ of study participants self-reported no physical activity and $13.4 \%$ self-reported tobacco use. Concerning dietary habits, over half of the participants self-reported that their usual diet included at least $60 \%$ of organic food. Tap, bottled, spring (well or natural source) and filtered water, beer and fruit juice consumption were also reported in the questionnaire. Occupational status and working environment were also reported: notably, $6.3 \%$ of the participants were farmers and $28.6 \%$ were retired from the general population. A higher proportion of participants reported working in a countryside environment than in an urban environment; of note, $7.5 \%$ of the participants worked in a winegrowing environment.

\section{Glyphosate is detected in $\mathbf{9 9 . 8 \%}$ of the samples and is higher during spring and summer}

Glyphosate was quantitatively detected in 6781 urine samples out of 6795 (99.8\%). In association analysis, measurements below the LOQ $(0.075 \mathrm{ng} / \mathrm{ml})$ were considered to be
Fig. 1 Geographical location of participants' residence. Plot sizes are proportional to the number of participants
Number of samples

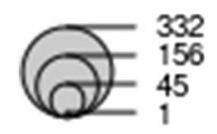

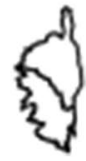


Table 1 Participants' self-reported biological, socio-demographic, and lifestyle information $(N=5800)$

\begin{tabular}{|c|c|}
\hline Characteristics & Study participants \\
\hline Protocol compliance (\%) & 82.3 \\
\hline Age (years) & 53 [0.5-94] \\
\hline Gender $(M / F$ ratio $)$ & 0.85 \\
\hline \multicolumn{2}{|l|}{ BMI, $\mathrm{kg} / \mathrm{m}^{2}(\%)$} \\
\hline Underweight, $\leq 18.5$ & 7.0 \\
\hline Normal range, 18.5-24.9 & 67.4 \\
\hline Overweight, 25.0-29.9 & 20.7 \\
\hline Class I obesity, 30.0-34.9 & 3.8 \\
\hline Class II obesity, 35.0-39.9 & 0.8 \\
\hline Class III obesity, $\geq 40.0$ & 0.2 \\
\hline \multicolumn{2}{|l|}{ Physical activity (\%) } \\
\hline Never & 11.0 \\
\hline Occasionally & 27.6 \\
\hline Regular basis & 61.4 \\
\hline Smokers (\%) & 13.4 \\
\hline \multicolumn{2}{|c|}{ Proportion of organic food consumption (\%) } \\
\hline$<40 \%$ & 17.3 \\
\hline $40-60 \%$ & 24.2 \\
\hline$>60 \%$ & 58.4 \\
\hline \multicolumn{2}{|l|}{ Tap water consumption (\%) } \\
\hline Never or rarely & 21.7 \\
\hline Occasionally & 8.8 \\
\hline Every day or almost & 69.5 \\
\hline \multicolumn{2}{|l|}{ Spring water consumption (\%) } \\
\hline Never or rarely & 80.6 \\
\hline Occasionally & 10.1 \\
\hline Every day or almost & 9.2 \\
\hline \multicolumn{2}{|l|}{ Filtered water consumption (\%) } \\
\hline Never or rarely & 73.0 \\
\hline Occasionally & 4.3 \\
\hline Every day or almost & 22.7 \\
\hline \multicolumn{2}{|l|}{ Beer consumption (\%) } \\
\hline Never or rarely & 42.4 \\
\hline Occasionally & 49.9 \\
\hline Every day or almost & 7.7 \\
\hline \multicolumn{2}{|l|}{ Fruit juice consumption (\%) } \\
\hline Never or rarely & 40.1 \\
\hline Occasionally & 44.4 \\
\hline Every day or almost & 15.5 \\
\hline \multicolumn{2}{|l|}{ Employment status (\%) } \\
\hline Retired & 28.6 \\
\hline Farmers & 6.3 \\
\hline Unemployed & 5.8 \\
\hline Children & 4.2 \\
\hline Other activity & 55.1 \\
\hline \multicolumn{2}{|l|}{ Working environment* (\%) } \\
\hline Urban area & 56.7 \\
\hline Countryside (excluding vineyards) & 59.2 \\
\hline Vineyards & 7.5 \\
\hline
\end{tabular}

* Several answers could be given. equal to $0.0 \mathrm{ng} / \mathrm{ml}$. BMI-adjusted glyphosate mean level was $1.19 \mathrm{ng} / \mathrm{ml}+/-0.84$, with a range $[<0.075 ; 7.36]$.

Data from the 5800 questionnaires were used to evaluate glyphosate levels according to the season of collection. Urine samples collected between May and September showed significantly higher glyphosate levels than those collected between October and April (Table 2; $p<0.001$ ).

Some urine collection sessions were repeated in the same geographical district: 1796 samples collected at least at 4 different times of the year in the same geographical district were available. Glyphosate measurements confirmed a higher level in spring-summer than in fall-winter (Table 2; $p<0.001)$.

\section{Glyphosate level is higher in first-void urine}

Participants who reported to have urinated less than $6 \mathrm{~h}$ before urine collection $(N=983)$ displayed lower glyphosate level than participants who complied with the protocol $(N=4583)(0.95 \mathrm{ng} / \mathrm{ml}+/-0.67$ vs. $1.24 \mathrm{ng} / \mathrm{ml}+/-0.83$; $p<0.001)$.

\section{Glyphosate level is higher in men and in younger participants and decreases with age}

Male participants $(N=2583)$ had higher mean glyphosate levels than women $(N=3040)(1.27 \mathrm{ng} / \mathrm{ml}+/-0.84$ vs. $1.13 \mathrm{ng} / \mathrm{ml}+/-0.83 ; p<0.001)$. Glyphosate levels were also higher in the youngest participants, with a continuous decrease with age (Table $3, p<0.001$ ).

\section{Glyphosate level is associated with smoking and dietary habits}

\section{Smoking is associated with higher glyphosate levels}

Glyphosate level was higher in tobacco users $(N=717)$ than in non-smokers or former smokers $(N=4930)(1.43 \mathrm{ng} /$ $\mathrm{ml}+/-0.91$ vs. $1.16 \mathrm{ng} / \mathrm{ml}+/-0.82 ; p<0.001)$.

Table 2 BMI-adjusted glyphosate levels (ng/ml) according to seasons in all samples from France, and in samples collected in the same district at various seasons

\begin{tabular}{lll}
\hline & Spring-summer & Fall-winter \\
\hline All samples $(N=5647)$ & $1.40+/-0.93$ & $1.05+/-0.74$ \\
Samples from same district & $1.43+/-0.88$ & $1.05+/-0.75$ \\
$(N=1796)$ & & \\
\hline
\end{tabular}


Table 3 BMI-adjusted glyphosate level (ng/ml) according to participants' age

\begin{tabular}{ll}
\hline Age (years) & Glyphosate level $(\mathrm{ng} / \mathrm{ml})$ \\
\hline$<16(N=217)$ & $2.05+/-1.29$ \\
$16-39(N=1192)$ & $1.44+/-0.92$ \\
$40-49(N=1019)$ & $1.26+/-0.83$ \\
$50-59(N=1183)$ & $1.11+/-0.73$ \\
$60-69(N=1521)$ & $0.99+/-0.67$ \\
$70-79(N=468)$ & $0.93+/-0.70$ \\
$>79(N=37)$ & $0.67+/-0.58$ \\
\hline
\end{tabular}

Table 4 BMI-adjusted glyphosate level (ng/ml) according to participants' organic food consumption

\begin{tabular}{ll}
\hline Organic food consumption & Glyphosate level $(\mathrm{ng} / \mathrm{ml})$ \\
\hline No $(N=216)$ & $1.17+/-0.80$ \\
Yes $(N=5271)$ & $1.19+/-0.84$ \\
Yes, less than $85 \%(N=3875)$ & $1.21+/-0.85$ \\
Yes, more than $85 \%(N=1327)$ & $1.16+/-0.80$ \\
\hline
\end{tabular}

\section{Major organic food consumption is associated with lower glyphosate level}

No statistically significant difference was observed between participants who consume organic food (any percentage) $(N=5271)$ and those who do not consume any organic food $(N=216)$ (Table $4 ; 1.19 \mathrm{ng} / \mathrm{ml}+/-0.84$ vs. $1.17 \mathrm{ng} /$ $\mathrm{ml}+/-0.80 ; p=0.68)$. However, participants who reported eating more than $85 \%$ of organic food $(N=1327)$ displayed lower glyphosate level than other participants $(N=3875)$ $(1.16 \mathrm{ng} / \mathrm{ml}+/-0.80$ vs. $1.21 \mathrm{ng} / \mathrm{ml}+/-0.85 ; p=0.026)$.

\section{Beer and fruit juice consumption are associated with higher glyphosate level}

Participants who drank beer had significantly higher glyphosate concentrations than other participants over 15 years old (Table 5; $p<0.001$ ). Participants who drank fruit juice displayed higher glyphosate levels than non-consumers (Table 6; $p=0.009$ ).

\section{Tap and spring water consumption are associated with higher glyphosate levels whereas filtered water consumption is associated with lower glyphosate levels}

Participants who drank tap water or spring water presented higher glyphosate levels (Table 7; $p=0.011$ and Table 8; $p=0.025)$. Filtered water consumption was associated with lower glyphosate levels (Table 9; $p<0.001$ ). Bottled water
Table 5 BMI-adjusted glyphosate level (ng/ml) according to participants' beer consumption

\begin{tabular}{ll}
\hline Beer consumption & Glyphosate level $(\mathrm{ng} / \mathrm{ml})$ \\
\hline Never $(N=2153)$ & $1.17+/ 0.87$ \\
Occasionally $(N=2542)$ & $1.20+/-0.81$ \\
Regular basis $(N=378)$ & $1.37+/-0.80$ \\
\hline
\end{tabular}

Table 6 BMI-adjusted glyphosate level (ng/ml) according to participants' fruit juice consumption

\begin{tabular}{ll}
\hline Fruit juice consumption & Glyphosate level $(\mathrm{ng} / \mathrm{ml})$ \\
\hline Never $(N=2151)$ & $1.16+/-0.81$ \\
Occasionally $(N=2372)$ & $1.21+/-0.86$ \\
Regular basis $(N=829)$ & $1.25+/-0.85$ \\
\hline
\end{tabular}

Table 7 BMI-adjusted glyphosate level (ng/ml) according to participants' tap water consumption

\begin{tabular}{ll}
\hline Tap water consumption & Glyphosate level $(\mathrm{ng} / \mathrm{ml})$ \\
\hline Never $(N=1208)$ & $1.13+/-0.82$ \\
Occasionally $(N=492)$ & $1.23+/-0.87$ \\
Regular basis $(N=3874)$ & $1.20+/-0.83$ \\
\hline
\end{tabular}

Table 8 BMI-adjusted glyphosate level (ng/ml) according to participants' spring water consumption

\begin{tabular}{ll}
\hline Spring water consumption & Glyphosate level $(\mathrm{ng} / \mathrm{ml})$ \\
\hline Never $(N=4494)$ & $1.18+/-0.83$ \\
Occasionally $(N=565)$ & $1.27+/-0.87$ \\
Regular basis $(N=514)$ & $1.23+/-0.90$ \\
\hline
\end{tabular}

consumption was not associated with a change in glyphosate mean level ( $p=0.83$, data not shown). Most participants ticked several types of filter (including carbon filter, other filter, reverse osmosis, softener); thus, no association with a specific filter could be identified.

\section{Glyphosate level is associated to occupational exposure}

Glyphosate levels were analyzed according to employment status. Farmers $(N=342)$ had significantly higher glyphosate concentrations than other participants over 15 years old $(N=4883)(1.29 \mathrm{ng} / \mathrm{ml}+/-0.84$ vs. $1.15 \mathrm{ng} / \mathrm{ml}+/-0.79$; $p=0.002)$.

When the specific work environment was considered, farmers working in a wine-growing environment $(N=63)$ presented higher glyphosate levels than other farmers 
Table 9 BMI-adjusted glyphosate level (ng/ml) according to participants' filtered water consumption

\begin{tabular}{ll}
\hline Filtered water consumption & Glyphosate level $(\mathrm{ng} / \mathrm{ml})$ \\
\hline Never $(N=4061)$ & $1.21+/-0.84$ \\
Occasionally $(N=243)$ & $1.31+/-0.94$ \\
Regular basis $(N=1268)$ & $1.12+/-0.80$ \\
\hline
\end{tabular}

$(N=279)(1.56 \mathrm{ng} / \mathrm{ml}+/-0.98$ vs. $1.22 \mathrm{ng} / \mathrm{ml}+/-0.79 ;$ $p=0.004)$.

\section{Discussion}

France is an important agricultural country, with half of its surface area dedicated to farming. During the last decades, the dominant French agricultural model evolved towards more intensive agriculture with an increased use of chemicals; France is among the top ten pesticide-consuming countries worldwide and is number one in the EU (Sharma et al. 2019).

Glyphosate has been extensively used since its commercialization in the 1970s in countries with intensive farming (reviewed in (Sharma et al. 2019)). Several methods have been developed and validated to measure glyphosate levels (reviewed in (Valle et al. 2019)). However, comparison of datasets needs to be carried out with caution, because of differences in sampling strategy, urinary dilution adjustments, or detection/quantification methods and limits (Connolly et al. 2020a). Accordingly, epidemiological studies on glyphosate have reported variable results. In Europe, the mean range of glyphosate levels was 0.16 to $7.6 \mathrm{ng} / \mathrm{ml}$ with detection frequencies in EU-states ranging between 10 and 90\% (Conrad et al. 2017; Gillezeau et al. 2019; Connolly et al. 2020a; Nova et al. 2020). Little data is available concerning glyphosate levels in the French general population. A study conducted in an adult cohort on several pesticides (classified as organophosphorus, pyrethroid and azole compounds) showed lower exposure, based on urine sample levels, in frequent organic food consumers (Baudry et al. 2019).

The present study included 6848 participants recruited between June 2018 and January 2020. The whole of France was covered except the north-east area, and to a lesser extent, a corridor from the north east to the south west. Glyphosate was quantified in urine samples using ELISA assay by a single laboratory $(N=6795)$. Measuring glyphosate concentration on a single urinary spot early morning after an overnight fast has been assessed to be a reliable estimation of maximum glyphosate excretion in humans. Two experimental studies carried out on humans showed that urinary elimination of glyphosate followed a two-phase excretion, with an initial rapid phase between 6 and $9 \mathrm{~h}$ followed by a slower phase (Zoller et al. 2020; Faniband et al. 2021).

The ELISA method applied to glyphosate detection and quantification offers an alternative approach to the drawbacks of chromatographic techniques, such as the requirement of derivatization procedures, sample pre-treatments, costly equipment, and the speed of reactions and analysis. ELISA and HPLC methods show comparable performances in terms of accuracy and precision for the detection and quantification of glyphosate in water samples (Clegg et al. 1999; Rubio et al. 2003), as do ELISA and LC/MS methods in water (Byer et al. 2008). Although there is a strong correlation between ELISA and HPLC methods, Clegg et al. (Clegg et al. 1999) showed that glyphosate values determined by ELISA were greater than those obtained by the HPLC method. These results were confirmed in ELISA validation tests performed on 14 human urine samples; GC-MS and ELISA methods showed a correlation coefficient of 0.87 and mean values obtained with ELISA were higher (Krüger et al. 2014). Higher values of pesticides quantified by ELISA than by HPLC were also observed for atrazine mercapturate and chlorpyrifos (Curwin et al. 2010).

Thus, these methodological differences should be kept in mind concerning our results supporting a general contamination of the French population, with glyphosate quantifiable in $99.8 \%$ of urine samples and a mean of $1.19 \mathrm{ng} /$ $\mathrm{ml}+/-0.84$.

Nevertheless, the biological, dietary habits and sociodemographic data association analyses performed here on a nationwide cohort, confirmed previously published data on glyphosate contamination.

Several studies performed with ELISA or LC methods found comparable results to ours in the general population in the USA, Denmark, or Sri Lanka (Curwin et al. 2007; Jayasumana et al. 2014; McGuire et al. 2016; Knudsen et al. 2017; Parvez et al. 2018; Lesseur et al. 2021), whereas other studies performed with GC or LC methods reported lower values in the USA, Germany, Portugal, or Spain (Mills et al. 2017; Connolly et al. 2018; Connolly et al. 2020a, b; Nova et al. 2020; Ruiz et al. 2021).

Compliance to the protocol (first-void urine collection) was associated with significantly higher glyphosate levels. These results support that delayed glyphosate excretion leads to higher urine concentrations. Some studies adjusted their results by a measurement of urinary dilution, mostly using creatinine. Experimental glyphosate intake followed by continuous assay monitoring recommended to adjust the urine dilution to obtain a better correlation (Zoller et al. 2020; Faniband et al. 2021); unadjusted and adjusted urinary excretion curves presented by Faniband et al. were very similar especially during the first $9 \mathrm{~h}$ (Faniband et al. 2021). However, creatinine is described to be affected by several factors as diet, age, sex, health status, including diabetes 
or kidney disorders. Other studies suggested to determine urine concentration by its specific gravity. All the tests used to measure urine specific gravity have certain limitations based on their underlying physical principles (Chadha et al. 2001). Since creatinine and specific gravity have drawbacks and an additional cost, concentration was adjusted according to BMI (Boeniger et al. 1993).

Our results seem to show a greater glyphosate intake in spring time. A former study showed that pesticides were more detected in groundwater during spring (McManus et al. 2014). Moreover, a Canadian study showed a bimodal glyphosate temporal distribution with peak concentrations occurring in late spring/early summer and fall (Byer et al. 2008). However, as no urine volume adjustment was performed and because people may excrete smaller volumes of urine during spring-summer than in winter, this result requires further investigation for confirmation.

Analysis of questionnaires revealed specificities of this participant cohort compared to the general population: older median age, more women, more physical activity, and less smokers (Galey et al. 2020, Pasquereau et al. 2020). Participants also displayed specific dietary habits with a greater organic food consumption (AgenceBio 2021). A high proportion of participants were farmers, including workers in a wine-growing environment (Cnav 2021). Recruitment was based on voluntary participation, which would explain such cohort specificities of citizens sensitized to pesticide issues and to living a healthy lifestyle.

Our results revealed an association between glyphosate levels and participant characteristics, as men presented higher glyphosate levels. Higher levels in men were previously reported (Conrad et al. 2017). Importantly, glyphosate also showed an inverse correlation with age, with the highest values in participants aged under 15 , as previously reported (Curwin et al. 2007; Fagan et al. 2020). Higher glyphosate levels found in the youngest participants may be associated with dietary habits (especially infant cereal), physiology and metabolism (children breathe and drink twice more than adults), physical activities, behavior and hygiene patterns with higher soil ingestion (Moya et al. 2004; Ginsberg et al. 2016). The results presented here are comparable with those reported in Portugal (Ferreira et al. 2021) and in Denmark (Knudsen et al. 2017), both carried out by ELISA method and are higher than those reported in Germany (Lemke et al. 2021) or in the USA (Trasande et al. 2020).

Results according to dietary habits highlighted contamination by food intake as lower glyphosate levels were associated both with dominant consumption of organic food and of filtered water. No association with a specific filter could have be identified as most participants reported using several kinds of filter (including carbon filter, other filter, reverse osmosis, softener). Organic food consumption was previously shown to be associated with lower glyphosate levels (Fagan et al. 2020) or with lower levels of pesticides (Baudry et al. 2019). Both tap water and spring water consumption were associated with higher glyphosate values as compared to filtered water. Water contamination is common and likely as glyphosate is polar and water soluble. Monitoring pesticide residues in EU agricultural topsoil collected between 2015 and 2018 showed a maximum of 16 residues/ sample with glyphosate being the most frequently detected and in highest contents (Geissen et al. 2021).

We also observed that higher glyphosate urine levels are associated with high beer and fruit juice consumption in concordance with studies showing noticeable glyphosate levels in beers and fruit juices (Zoller et al. 2018) and with reports showing that the number of chemical sprays per crop is the highest for fruit (Agreste 2020a, e).

Higher occupational exposure to pesticides was confirmed as farmers and more particularly farmers working in a wine-growing environment displayed higher glyphosate levels (respectively $1.29 \mathrm{ng} / \mathrm{ml}$ and $1.56 \mathrm{ng} / \mathrm{ml}$ ). These results are supported by previously published data showing high levels in occupationally exposed groups, with mean values ranging from 1.35 to $3.2 \mathrm{ng} / \mathrm{ml}$ (Connolly et al. 2020a; Zhang et al. 2020). Two different studies performed with LC methods (Connolly et al. 2017, 2018) reported results that were comparable and lower than ours. The higher exposure levels found in farmers working in wine-growing may be due to a more intensive use of pesticides in vineyards (Agreste 2020a, e); in France in 2006, wine-growing represented $3.3 \%$ of agricultural land, whereas their pesticide consumption in euros was 14.4\% (Butault et al. 2011). Furthermore, the use of plant protection products increased by $21 \%$ in wine-growing between 2010 and 2016 (Agreste 2019).

Thus, our present results on more than 6000 participants in various parts of the country firmly support a general contamination of the French population with glyphosate, with a significant seasonal effect backing contamination from external exposure. Our data confirm previous studies supporting higher levels in the young, in men and in occupationally exposed individuals. We also confirm glyphosate contamination via ingestion and inhalation, as lower levels of glyphosate were observed in individuals who mainly ate organic food and drank filtered water, while higher levels were found in tobacco users, glyphosate being used nowadays as a desiccant for some crops before harvest.

Our results are globally consistent with the data in international literature and show a large exposure of the French population to glyphosate-based herbicides. On the whole, this exposure seems comparable or slightly higher than that measured in inhabitants of other industrial countries.

It should be noted that our results do not allow to estimate the actual level of glyphosate daily intake in the population. The relevance of measuring the level of glyphosate in urine as a reliable estimate of exposure is a major methodological 
issue. Until recently, data were only available from laboratory animal studies, with excretion rates of approximately $20 \%$ of an orally administered dose of glyphosate (EFSA 2015). It was recently demonstrated, however, that about only $1 \%$ of the glyphosate dose was excreted in human urine within $44 \mathrm{~h}$ (Faniband et al. 2021). An accurate quantification of exposure, whether by internal or external route, is a major public health concern as toxicity evaluation relies on absorbed dose estimates (IARC 2015).

Our results concerning a higher contamination during spring and summer, along with a higher level found in nonfiltered water consumers also raise the question of environmental contamination, supported by the widespread glyphosate contamination of honey (Zoller et al. 2018). Many studies associated pesticide use with the decline in numbers of insects and birds (Jactel et al. 2021). Moreover, resistance to glyphosate is a well-described mechanism (Sammons and Gaines 2014) that arises in several weed species, driven by rapid and different biological processes in response to abiotic selective pressure (Patterson et al. 2018, 2019). The fast and independent evolution in multiple species of resistance mechanisms to glyphosate makes it necessary to increase glyphosate applications to obtain an equivalent lethal effect. Accordingly, population exposure seems to have increased during the 2000s, as supported by a study carried out in Germany (Conrad et al. 2017).

In conclusion, our data further contribute to the description of a widespread glyphosate contamination of the population in industrialized countries and raise the question of the sustainability of widespread and repeated use of glyphosate. Glyphosate and pesticides, in general, are described as being harmful to both farmers' health and biodiversity, with longlasting environmental contamination. Although organic food production is continuously increasing in France (Agreste 2020c), glyphosate is still authorized in French and EU agriculture and the CAP (Common Agricultural Policy) recently adopted by European Union may not be strong enough to implement and support a transition towards a new agricultural model (Massot Marti 2020) rising to the challenge of food supply, farmers' income and health and biodiversity.

Acknowledgements The authors thank all participants, local committees' organizers, and Campagne Glyphosate France Association.

Author contribution DG, NG, and QG contributed to the conception and design of the study; DG and CP organized the database and performed the statistical analysis; all authors contributed to the analysis and interpretation of data; JDC wrote the first draft of the manuscript. All authors contributed to manuscript revision, read and approved the submitted version.

Funding The present study was launched by a non-profit organization and performed based on a concerned citizen participatory process involving volunteers that all individually supported the financial cost of urine sample collection and glyphosate laboratory assay along with bailiff control. No institutional funding supported the collection of all data as well as the scientific treatment of the data and article writing.

Data availability The datasets used and/or analyzed during the current study are available from the corresponding author on reasonable request.

\section{Declarations}

Ethics approval and consent to participate Ethics approval was waived; all participants gave written informed consent for participation in the study prior to sample collection.

Consent to publish All participants gave written informed consent for participation in the study and its publication.

Competing interests Cécile Stratonovitch is a member of the board of directors of the association "Alerte des médecins sur les pesticides," dedicated to providing information on the health effects of pesticides, on a non-profit basis. All other authors declare no competing interests.

Open Access This article is licensed under a Creative Commons Attribution 4.0 International License, which permits use, sharing, adaptation, distribution and reproduction in any medium or format, as long as you give appropriate credit to the original author(s) and the source, provide a link to the Creative Commons licence, and indicate if changes were made. The images or other third party material in this article are included in the article's Creative Commons licence, unless indicated otherwise in a credit line to the material. If material is not included in the article's Creative Commons licence and your intended use is not permitted by statutory regulation or exceeds the permitted use, you will need to obtain permission directly from the copyright holder. To view a copy of this licence, visit http://creativecommons.org/licenses/by/4.0/.

\section{References}

Acquavella JF, Alexander BH, Mandel JS, Gustin C, Baker B, Chapman P, Bleeke M (2004) Glyphosate biomonitoring for farmers and their families: results from the Farm Family Exposure Study. Environ Health Perspect 112(3):321-326

AgenceBio (2021). baromètre de consommation et de perception des produits biologiques en France. S. I. Edition

Agreste (2019). Enquête Pratiques phytosanitaires en viticulture en 2016: Nombre de traitements et indicateurs de fréquence de traitement, Ministère de l'Agriculture et de l'Alimentation

Agreste (2020a). Enquête pratiques culturales en grandes cultures et prairies 2017 - Principaux résultats, Ministère de l'Agriculture et de l'Alimentation

Agreste (2020b). Exploitation, Foncier, Installation, Ministère de l'Agriculture et de l'Alimentation

Agreste (2020c). Infographie - L'agriculture biologique en France, Ministère de l'Agriculture et de l'Alimentation

Agreste (2020d). Population Agricole, formation et Recherche, Ministère de l'Agriculture et de l'Alimentation

Agreste (2020e). Pratiques de Culture et d'Elevage, Ministère de l'Agriculture et de l'Alimentation

Alarcon R, Ingaramo PI, Rivera OE, Dioguardi GH, Repetti MR, Demonte LD, Milesi MM, Varayoud J, Munoz-de-Toro M, Luque EH (2019) Neonatal exposure to a glyphosate-based herbicide alters the histofunctional differentiation of the ovaries and uterus in lambs. Mol Cell Endocrinol 482:45-56 
ANSES (2016). Total Infant Feeding Study Volume 2 - Part 4 Results on pesticide residues Agence Nationale de Sécurité Sanitaire. Tome 2 - Partie 4

ANSES (2019). "Phytopharmacovigilance Glyphosate Summary of surveillance data Scientific and technical support." (Report No $\therefore \mathrm{n}^{\circ} 2017-04$ )

Baudry J, Debrauwer L, Durand G, Limon G, Delcambre A, Vidal R, Taupier-Letage B, Druesne-Pecollo N, Galan P, Hercberg S, Lairon D, Cravedi JP, Kesse-Guyot E (2019) Urinary pesticide concentrations in French adults with low and high organic food consumption: results from the general population-based NutriNet-Sante. J Expo Sci Environ Epidemiol 29(3):366-378

Benbrook CM (2019) How did the US EPA and IARC reach diametrically opposed conclusions on the genotoxicity of glyphosatebased herbicides? Environ Sci Eur 31(1):2

Boeniger MF, Lowry LK, Rosenberg J (1993) Interpretation of urine results used to assess chemical exposure with emphasis on creatinine adjustments: a review. Am Ind Hyg Assoc J 54(10):615-627

Butault J-P, Delame N, Jacquet F, Zardet G (2011). L'utilisation des pesticides en France : état des lieux et perspectives de réduction. C. D. É. E. D. PROSPECTIVE, Ministère de l'Agriculture et de l'Alimentation. NESE $n^{\circ}$ 35, octobre 2011, : 7-26

Byer JD, Struger J, Klawunn P, Todd A, Sverko E (2008) Low cost monitoring of glyphosate in surface waters using the ELISA method: an evaluation. Environ Sci Technol 42(16):6052-6057

Chadha V, Garg U, Alon US (2001) Measurement of urinary concentration: a critical appraisal of methodologies. Pediatr Nephrol 16(4):374-382

Chevrier C., P. C., Limon G., Monfort C., Durand G., Cordier S. (2009). Public Health France. Urinary biomarkers of exposure to pesticides in pregnant women in the Pelagie cohort carried out in Brittany, France (2002-2006). Bulletin Epidémiologique Hebdomadaire, Santé Publique France: 23-27

Clegg BS, Stephenson GR, Hall JC (1999) Development of an enzymelinked immunosorbent assay for the detection of glyphosate. J Agric Food Chem 47(12):5031-5037

Cnav (2021). Nombre de retraités en paiement au 31 décémbre 2020. r. e. p. d. 1. C. n. d. a. v. Statistiques, Sécurité Sociale

Connolly, A., M. A. Coggins and H. M. Koch (2020a). "Human biomonitoring of glyphosate exposures: state-of-the-art and future research challenges." Toxics 8(3)

Connolly A, Jones K, Galea KS, Basinas I, Kenny L, McGowan P, Coggins $\mathbf{M}$ (2017) Exposure assessment using human biomonitoring for glyphosate and fluroxypyr users in amenity horticulture. Int J Hyg Environ Health 220(6):1064-1073

Connolly A, Koslitz S, Bury D, Bruning T, Conrad A, Kolossa-Gehring M, Coggins MA, Koch HM (2020) Sensitive and selective quantification of glyphosate and aminomethylphosphonic acid (AMPA) in urine of the general population by gas chromatography-tandem mass spectrometry. J Chromatogr B Analyt Technol Biomed Life Sci 1158:122348

Connolly A, Leahy M, Jones K, Kenny L, Coggins MA (2018) Glyphosate in Irish adults - A pilot study in 2017. Environ Res 165:235-236

Conrad A, Schroter-Kermani C, Hoppe HW, Ruther M, Pieper S, Kolossa-Gehring M (2017) Glyphosate in German adults - Time trend (2001 to 2015) of human exposure to a widely used herbicide. Int J Hyg Environ Health 220(1):8-16

Curwin BD, Hein MJ, Barr DB, Striley C (2010) Comparison of immunoassay and HPLC-MS/MS used to measure urinary metabolites of atrazine, metolachlor, and chlorpyrifos from farmers and nonfarmers in Iowa. J Expo Sci Environ Epidemiol 20(2):205-212

Curwin BD, Hein MJ, Sanderson WT, Striley C, Heederik D, Kromhout H, Reynolds SJ, Alavanja MC (2007) Pesticide dose estimates for children of Iowa farmers and non-farmers. Environ Res 105(3):307-315
Dallegrave E, Mantese FD, Oliveira RT, Andrade AJ, Dalsenter PR, Langeloh A (2007) Pre- and postnatal toxicity of the commercial glyphosate formulation in Wistar rats. Arch Toxicol 81(9):665-673

de Araujo JS, Delgado IF, Paumgartten FJ (2016) Glyphosate and adverse pregnancy outcomes, a systematic review of observational studies. BMC Public Health 16:472

EFSA (2015) Conclusion on the peer review of the pesticide risk assessment of the active substance glyphosate. EFSA J 13(11):4302

Fagan J, Bohlen L, Patton S, Klein K (2020) Organic diet intervention significantly reduces urinary glyphosate levels in U.S. children and adults. Environ Res 189:109898

Faniband MH, Noren E, Littorin M, Lindh CH (2021) Human experimental exposure to glyphosate and biomonitoring of young Swedish adults. Int J Hyg Environ Health 231:113657

Ferreira C, Duarte SC, Costa E, Pereira A, Silva LJG, Almeida A, Lino C, Pena A (2021) Urine biomonitoring of glyphosate in children: exposure and risk assessment. Environ Res 198:111294

Foucart S (2021a) Glyphosate : l'expertise européenne a exclu de son analyse l'essentiel de la littérature scientifique. Le Monde. 16 novembre 2021

Foucart S (2021b) Glyphosate: des études réglementaires non fiables. Le Monde. 5 juillet 2021

Franz J (1974) N-phosphonomethyl-glycine phytotoxicant compositions. US, Monsanto Co

Galey CVC, Salanave B, Caruso A, Pelé T, Lemonnier F, Richard J-B (2020) La pratique sportive chez les adultes en France en 2017 et évolutions depuis 2000 : résultats du Baromètre de Santé publique France. É. e. enquêtes, Santé Publique France: 49

Garry VF, Harkins ME, Erickson LL, Long-Simpson LK, Holland SE, Burroughs BL (2002) Birth defects, season of conception, and sex of children born to pesticide applicators living in the Red River Valley of Minnesota, USA. Environ Health Perspect 110(Suppl 3):441-449

Geissen V, Silva V, Lwanga EH, Beriot N, Oostindie K, Bin Z, Pyne E, Busink S, Zomer P, Mol H, Ritsema CJ (2021) Cocktails of pesticide residues in conventional and organic farming systems in Europe - Legacy of the past and turning point for the future. Environ Pollut 278:116827

GénérationsFutures (2017) Exclusive research results for glyphosate in foods sold in France, Générations Futures Association loi 1901, membre de PAN Europe, HEAL et du Rassemblement pour la planète

Gillezeau C, van Gerwen M, Shaffer RM, Rana I, Zhang L, Sheppard L, Taioli E (2019) The evidence of human exposure to glyphosate: a review. Environ Health 18(1):2

Ginsberg G, Ginsberg J, Foos B (2016) "Approaches to children's exposure assessment: case study with diethylhexylphthalate (DEHP)." Int J Environ Res Public Health 13(7)

Gunarathna S, Gunawardana B, Jayaweera M, Manatunge J, Zoysa K (2018) Glyphosate and AMPA of agricultural soil, surface water, groundwater and sediments in areas prevalent with chronic kidney disease of unknown etiology, Sri Lanka. J Environ Sci Health B 53(11):729-737

Gunatilake S, Seneff S, Orlando L (2019). "Glyphosate's synergistic toxicity in combination with other factors as a cause of chronic kidney disease of unknown origin." Int J Environ Res Public Health 16(15)

Hussain S, AM, Springael D, SøRensen SR, Bending GD, DeversLamrani M, Maqbool Z, Martin-Laurent F (2015) Abiotic and biotic processes governing the fate of phenylurea herbicides in soils: a review. Crit Rev Environ Sci Technol 45(18):1947-1998

IARC (2015) IARC Monographs on the evaluation on carcinogenic risk on human. WHO Press, World Health Organization, p 112 
Ingaramo P, Alarcon R, Munoz-de-Toro M, Luque EH (2020) Are glyphosate and glyphosate-based herbicides endocrine disruptors that alter female fertility? Mol Cell Endocrinol 518:110934

INSEE (2020) Les agriculteurs : de moins en moins nombreux et de plus en plus d'hommes

Inserm (2021) Pesticides et effets sur la santé : Nouvelles données. Collection Expertise collective. M. E. Sciences, INSERM

Jactel H, Imler JL, Lambrechts 1, Failloux AB, Lebreton JD, Le Maho Y, Duplessy JC, Cossart P, Grandcolas P (2021) Insect decline: immediate action is needed. Comptes Rendus Biologies, Académie des Sciences

Jarrell ZR, Ahammad MU, Benson AP (2020) Glyphosate-based herbicide formulations and reproductive toxicity in animals. Vet Anim Sci 10:100126

Jauhiainen A, Rasanen K, Sarantila R, Nuutinen J, Kangas J (1991) Occupational exposure of forest workers to glyphosate during brush saw spraying work. Am Ind Hyg Assoc J 52(2):61-64

Jayasumana C, Gunatilake S, Senanayake P (2014) Glyphosate, hard water and nephrotoxic metals: are they the culprits behind the epidemic of chronic kidney disease of unknown etiology in Sri Lanka? Int J Environ Res Public Health 11(2):2125-2147

Knudsen LE, Hansen PW, Mizrak S, Hansen HK, Morck TA, Nielsen F, Siersma V, Mathiesen L (2017) Biomonitoring of Danish school children and mothers including biomarkers of PBDE and glyphosate. Rev Environ Health 32(3):279-290

Krüger M, Schledorn P, Schrödl W, Hoppe HW, Lutz W, Shehata AA (2014) "Detection of glyphosate residues in animals and humans." J Environ Anal Toxicol 4(2)

Lemke N, Murawski A, Schmied-Tobies MIH, Rucic E, Hoppe HW, Conrad A, Kolossa-Gehring M (2021) Glyphosate and aminomethylphosphonic acid (AMPA) in urine of children and adolescents in Germany - human biomonitoring results of the German Environmental Survey 2014-2017 (GerES V). Environ Int 156:106769

Leon ME, Schinasi LH, Lebailly P, Beane Freeman LE, Nordby KC, Ferro G, Monnereau A, Brouwer M, Tual S, Baldi I, Kjaerheim K, Hofmann JN, Kristensen P, Koutros S, Straif K, Kromhout H, Schuz J (2019) Pesticide use and risk of non-Hodgkin lymphoid malignancies in agricultural cohorts from France, Norway and the USA: a pooled analysis from the AGRICOH consortium. Int J Epidemiol 48(5):1519-1535

Lesseur C, Pirrotte P, Pathak KV, Manservisi F, Mandrioli D, Belpoggi F, Panzacchi S, Li Q, Barrett ES, Nguyen RHN, Sathyanarayana S, Swan SH, Chen J (2021) Maternal urinary levels of glyphosate during pregnancy and anogenital distance in newborns in a US multicenter pregnancy cohort. Environ Pollut 280:117002

Mandard SFS (2020). Le recours aux pesticides a connu une hausse spectaculaire en 2018, Le Monde

Manservisi F, Lesseur C, Panzacchi S, Mandrioli D, Falcioni L, Bua L, Manservigi M, Spinaci M, Galeati G, Mantovani A, Lorenzetti S, Miglio R, Andrade AM, Kristensen DM, Perry MJ, Swan SH, Chen J, Belpoggi F (2019) The Ramazzini Institute 13-week pilot study glyphosate-based herbicides administered at humanequivalent dose to Sprague Dawley rats: effects on development and endocrine system. Environ Health 18(1):15

Massot Marti, A (2020).Research for the AGRI Committee - The Green Deal and the CAP: policy implications to adapt farming practices and to preserve the EU's natural resources, INRAE AgroParis Tech European Parliament Think Tank

McGuire MK, McGuire MA, Price WJ, Shafii B, Carrothers JM, Lackey KA, Goldstein DA, Jensen PK, Vicini JL (2016) Glyphosate and aminomethylphosphonic acid are not detectable in human milk. Am J Clin Nutr 103(5):1285-1290

McManus SL, Richards KG, Grant J, Mannix A, Coxon CE (2014) Pesticide occurrence in groundwater and the physical characteristics in association with these detections in Ireland. Environ Monit Assess 186(11):7819-7836

Mills PJ, Kania-Korwel I, Fagan J, McEvoy LK, Laughlin GA, BarrettConnor E (2017) Excretion of the herbicide glyphosate in older adults between 1993 and 2016. JAMA 318(16):1610-1611

Moya J, Bearer CF, Etzel RA (2004) Children's behavior and physiology and how it affects exposure to environmental contaminants. Pediatrics 113(4 Suppl):996-1006

Nevison CD (2014) A comparison of temporal trends in United States autism prevalence to trends in suspected environmental factors. Environ Health 13:73

Nova P, Calheiros CSC, Silva M (2020) Glyphosate in Portuguese adults - a pilot study. Environ Toxicol Pharmacol 80:103462

Ongono JS, Beranger R, Baghdadli A, Mortamais M (2020) Pesticides used in Europe and autism spectrum disorder risk: can novel exposure hypotheses be formulated beyond organophosphates, organochlorines, pyrethroids and carbamates? - A systematic review. Environ Res 187:109646

Parvez S, Gerona RR, Proctor C, Friesen M, Ashby JL, Reiter JL, Lui Z, Winchester PD (2018) Glyphosate exposure in pregnancy and shortened gestational length: a prospective Indiana birth cohort study. Environ Health 17(1):23

Pasquereau A, AR, Arwidson P, Guignard R, Nguyen-Thanh V (2020) Tobacco use among adults: five-year review of the National Tobacco Control Programme, 2014-2019. Bull Epidémiol Hebd 14:273-281

Patterson EL, Pettinga DJ, Ravet K, Neve P, Gaines TA (2018) Glyphosate resistance and epsps gene duplication: convergent evolution in multiple plant species. J Hered 109(2):117-125

Patterson EL, Saski CA, Sloan DB, Tranel PJ, Westra P, Gaines TA (2019) The Draft genome of Kochia scoparia and the mechanism of glyphosate resistance via transposon-mediated EPSPS tandem gene duplication. Genome Biol Evol 11(10):2927-2940

Portier CJ, Armstrong BK, Baguley BC, Baur X, Belyaev I, Belle R, Belpoggi F, Biggeri A, Bosland MC, Bruzzi P, Budnik LT, Bugge MD, Burns K, Calaf GM, Carpenter DO, Carpenter HM, LopezCarrillo L, Clapp R, Cocco P, Consonni D, Comba P, Craft E, Dalvie MA, Davis D, Demers PA, De Roos AJ, DeWitt J, Forastiere F, Freedman JH, Fritschi L, Gaus C, Gohlke JM, Goldberg M, Greiser E, Hansen J, Hardell L, Hauptmann M, Huang W, Huff J, James MO, Jameson CW, Kortenkamp A, Kopp-Schneider A, Kromhout H, Larramendy ML, Landrigan PJ, Lash LH, Leszczynski D, Lynch CF, Magnani C, Mandrioli D, Martin FL, Merler E, Michelozzi P, Miligi L, Miller AB, Mirabelli D, Mirer FE, Naidoo S, Perry MJ, Petronio MG, Pirastu R, Portier RJ, Ramos KS, Robertson LW, Rodriguez T, Roosli M, Ross MK, Roy D, Rusyn I, Saldiva P, Sass J, Savolainen K, Scheepers PT, Sergi C, Silbergeld EK, Smith MT, Stewart BW, Sutton P, Tateo F, Terracini B, Thielmann HW, Thomas DB, Vainio H, Vena JE, Vineis P, Weiderpass E, Weisenburger DD, Woodruff TJ, Yorifuji T, Yu IJ, Zambon P, Zeeb H, Zhou SF (2016) Differences in the carcinogenic evaluation of glyphosate between the International Agency for Research on Cancer (IARC) and the European Food Safety Authority (EFSA). J Epidemiol Community Health 70(8):741-745

RCoreTeam (2020) R: A language and environment for statistical computing. Austria, R Foundation for Statistical Computing, Vienna

Rubio F, Veldhuis LJ, Clegg BS, Fleeker JR, Hall JC (2003) Comparison of a direct ELISA and an HPLC method for glyphosate determinations in water. J Agric Food Chem 51(3):691-696

Ruiz P, Dualde P, Coscolla C, Fernandez SF, Carbonell E, Yusa V (2021) Biomonitoring of glyphosate and AMPA in the urine of Spanish lactating mothers. Sci Total Environ 801:149688

Sammons RD, Gaines TA (2014) Glyphosate resistance: state of knowledge. Pest Manag Sci 70(9):1367-1377 
Savitz DA, Arbuckle T, Kaczor D, Curtis KM (1997) Male pesticide exposure and pregnancy outcome. Am J Epidemiol 146(12):1025-1036

Schulz R, Bub S, Petschick LL, Stehle S, Wolfram J (2021) Applied pesticide toxicity shifts toward plants and invertebrates, even in GM crops. Science 372(6537):81-84

Sharma A, Kumar V, Shahzad B, Tanveer M, Sidhu GPS, Handa N, Kohli SK, Yadav P, Bali AS, Parihar RD, Dar OI, Singh K, Jasrotia S, Bakshi P, Ramakrishnan M, Kumar S, Bhardwaj R, Thukral AK (2019) Worldwide pesticide usage and its impacts on ecosystem. SN Appl Sci 1(11):1446

Steinrucken HC, Amrhein N (1980) The herbicide glyphosate is a potent inhibitor of 5-enolpyruvyl-shikimic acid-3-phosphate synthase. Biochem Biophys Res Commun 94(4):1207-1212

Trasande L, Aldana SI, Trachtman H, Kannan K, Morrison D, Christakis DA, Whitlock K, Messito MJ, Gross RS, Karthikraj R, Sathyanarayana S (2020) Glyphosate exposures and kidney injury biomarkers in infants and young children. Environ Pollut 256:113334

Valle AL, Mello FCC, Alves-Balvedi RP, Rodrigues LP, Goulart LR (2019) Glyphosate detection: methods, needs and challenges. Environ Chem Lett 17(1):291-317

Varona M, Henao GL, Diaz S, Lancheros A, Murcia A, Rodriguez N, Alvarez VH (2009) Effects of aerial applications of the herbicide glyphosate and insecticides on human health. Biomedica 29(3):456-475

von Ehrenstein OS, Ling C, Cui X, Cockburn M, Park AS, Yu F, Wu J, Ritz B (2019) Prenatal and infant exposure to ambient pesticides and autism spectrum disorder in children: population based casecontrol study. BMJ 364:1962

Woodburn AT (2000) Glyphosate: production, pricing and use worldwide $\dagger$. Pest Manag Sci 56(4):309-312

WorldAtlas (2021) "top-pesticide-consuming-countries-of-the-world"

Zhang F, Xu Y, Liu X, Pan L, Ding E, Dou J, Zhu B (2020) "Concentration distribution and analysis of urinary glyphosate and its metabolites in occupationally exposed workers in Eastern China." Int J Environ Res Public Health 17(8)

Zhang L, Rana I, Shaffer RM, Taioli E, Sheppard L (2019) Exposure to glyphosate-based herbicides and risk for non-Hodgkin lymphoma: a meta-analysis and supporting evidence. Mutat Res 781:186-206

Zoller O, Rhyn P, Rupp H, Zarn JA, Geiser C (2018) Glyphosate residues in Swiss market foods: monitoring and risk evaluation. Food Addit Contam Part B Surveill 11(2):83-91

Zoller O, Rhyn P, Zarn JA, Dudler V (2020) Urine glyphosate level as a quantitative biomarker of oral exposure. Int J Hyg Environ Health 228:113526

Publisher's note Springer Nature remains neutral with regard to jurisdictional claims in published maps and institutional affiliations. 